\title{
Acne Keloidalis Nuchae - Case Report
}

\author{
Dejan OGORELICA ${ }^{1,2}$, Zorica GAJINOV ${ }^{1,2}$, Ljubinka MATOVIĆ ${ }^{1}$, Branislava GAJIĆ1,2, \\ Zoran GOLUŠIN ${ }^{1,2}$, Sanja JAKOVLJEVIĆ1,2
}

${ }^{1}$ Clinic of Dermatovenereology Diseases, Clinical Center of Vojvodina, Novi Sad, Serbia

${ }^{2}$ Faculty of Medicine, University of Novi Sad, Serbia

*Correspondence: Dejan Ogorelica, E-mail: ogorelica92@gmail.com

UDC 616.594.1-002

\begin{abstract}
Acne keloidalis nuchae (AKN) / folliculitis keloidalis nuchae (FKN) is a chronic inflammatory condition which involves hair follicles localized predominantly in occipital scalp and posterior neck area leading to hypertrophic scarring alopecia. We present a 59-year-old factory worker, Caucasian male with a whitish alopecic oval plaque about 10 $\mathrm{cm}$ in diameter in the occipital region. The peripheral part of plaque was mildly inflammated, with groups of tufted terminal hairs, while the central part showed cicatricial alopecia and discrete non-adherent dry scales. Skin changes firstly occurred 6 years earlier, as itchy papules and pustules that sometimes healed with scarring. The applied relevant diagnostic and therapeutical measures are discussed in this report.
\end{abstract}

Key words: Acne Keloid; Folliculitis; Diagnosis; Alopecia; Cicatrix; Case Reports; Therapeutics

\section{Introduction}

Acne keloidalis nuchae (AKN) /folliculitis keloidalis nuchae (FKN) is a chronic inflammatory condition which involves hair follicles predominantly localized in occipital scalp and posterior neck area leading to hypertrophic scarring alopecia. The disorder was first described in 1869 by Kaposi, who called it "dermatitis papillaris capillitii" (1). The term "acne keloidalis nuchae" was coined by Bazini in 1872 (2). AKN is the most prevalent in Afican American population, but it is also frequently observed among Hispanic and Asian men. However, it is rarely observed among Caucasian men $(3,4)$. AKN usually occurs in people aged 14-25 years and mostly affects males, with male-female ratio of approximately $20: 1(5,6)$.

\section{Case report}

We present a 59-year-old, factory worker, Caucasian male with a whitish alopetic oval plaque about $10 \mathrm{~cm}$ in diameter in the occipital region. The peripheral part of plaque was mildly inflammated, with groups of tufted terminal hairs, while the central part showed cicatricial alopecia and discrete non-adherent dry scales (Figure 1). Skin changes started

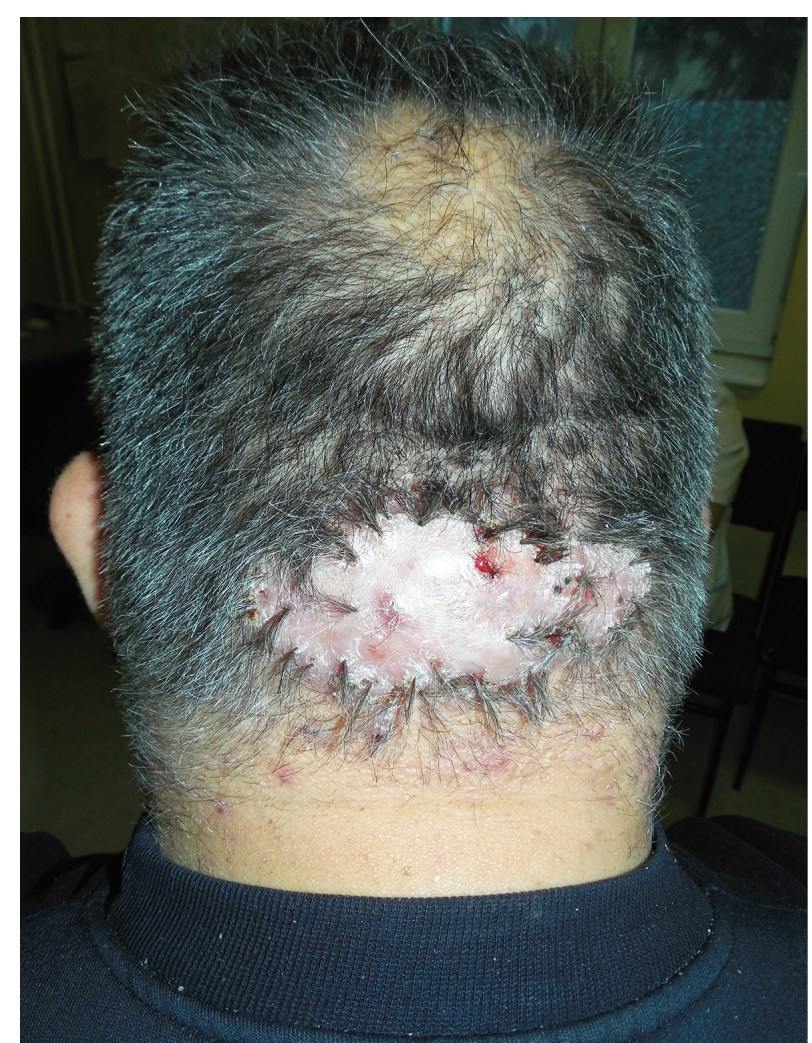

Figure 1. Clinical presentation of alopecic oval plaque in occipitial region 


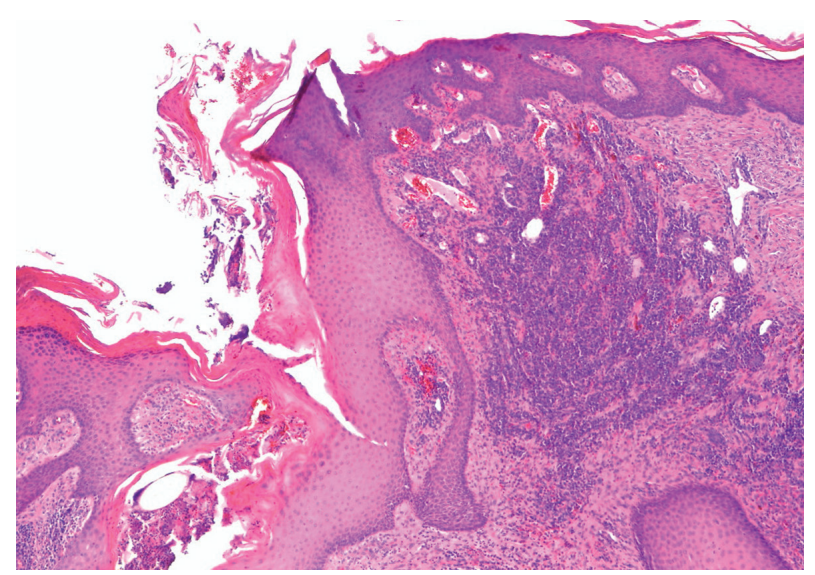

Figure 2. Inflammatory infiltration with plasma cell, neutrophilic granulocytes and giant multinucleated cells (hematoxylin and eosin, $x 20$ )

6 years earlier, as itchy papules and pustules that sometimes healed with scarring. For many years he had a short haircut. Short courses of oral antibiotics combined with topical antiseptic were administered on several occasions over the years. All relevant clinical and laboratory findings were within normal limits, except for slightly elevated bilirubin, higher sedimentation rate and $\mathrm{BMI}>$ 30. Biopsy was performed to exclude other causes of cicatricial alopecia (eg discoid lupus erythematosus, cicatricial lichen), confirming chronic inflammatory plasmocytic infiltrate with scarring, sparing the distal third of the follicle. Since the inflammation was under control with topical antiseptics and the process was contained, the patient was referred to a plastic surgeon.

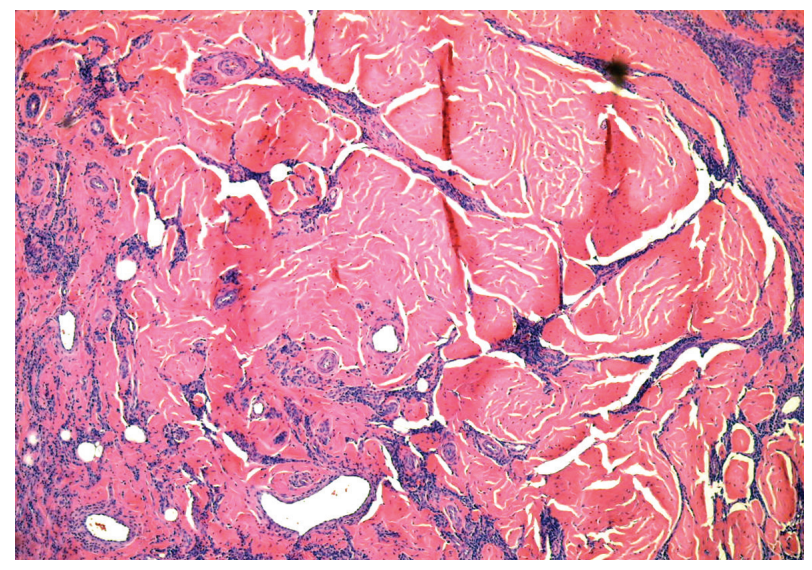

Figure 3. Dermal fibrosis (hematoxylin and eosin, $\times 50)$

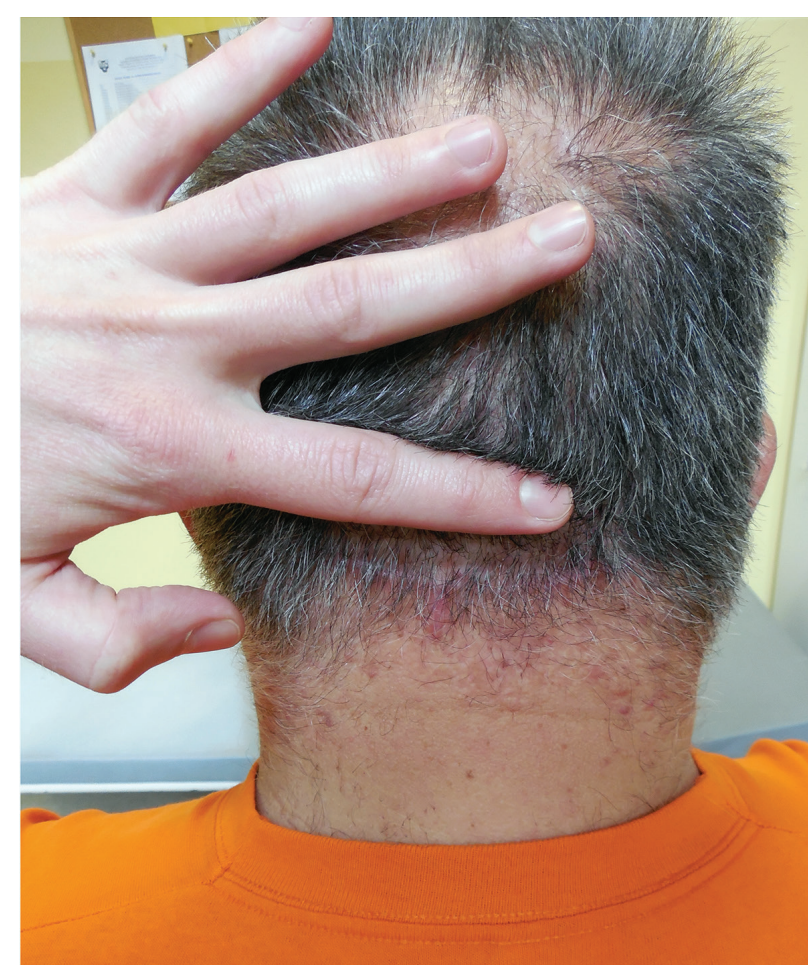

Figure 4. Clinical presentation seven months after surgical excision

Pathohistological analysis of the excised plaque showed hyperkeratotic epidermis with focal parakeratosis, perivascular chronic inflammatory infiltration with plasma cells, neutrophilic granulocytes and giant granulomatous cells, (Figure 2) without infiltrating the distal one-third of hair follicles. The significant fibrosis of dermis was also present (Figure 3).

Seven months after surgical procedure was performed, the patient was in remission with satisfactory cosmetic outcome (Figure 4).

\section{Discussion}

The cause of acne keloidalis is still unknown, but the suggested etiologies include different predisposing factors such as close shaving of the neck, constant irritation from collars or athletic gear, chronic low-grade bacterial infections, an autoimmune process, use of antiepileptic drugs or cyclosporine or an increased number of mast cells in the occipital region like those descibed in skin of African American population (7). Acne keloidalis nuchae occurs predominantly in males, suggesting that androgens may be a factor which contributes directly or indirectly. This 
disease rarely begins before puberty and it also seldom develops after the age of 55 (8).

Acne keloidalis usually starts with pruritus or mild irritation a few hours or days after a haircut or after wearing headwear sports gear. The disease is characterized by development of follicular papules or pustules on the nape of the neck below the hair line, and rarely extends upwards into the scalp. Pruritus, pain, and contact bleeding are common in active lesions. Pruritus sets up a cycle of itch, scratch, irritation and inflammation. Secondary bacterial infection, usually caused by Staphylococcus aureus, is frequent and can lead to pustules, sinuses and abscesses. Recurrence of this form of folliculitis leads to patchy scars, which can enlarge and form keloids. The scars are without hairs, however, multiple hair shafts emerged from a single follicular opening can form a look of tufted hairs. Inflammation begins in the upper one-third of the hair follicles. Crusting and excoriation may be evident (9). In advanced or severe cases, disfiguring tumor-like masses, abcesses and pus-exuding sinus tracks may be present $(10,11)$.

The histological examination depends on the duration and activity of the lesion. Initially, inflammatory infiltration is composed of neutrophils and lymphocytes, to predominantly plasma cells (12). In more chronic lesions, follicles and sebaceous glands are destroyed with fragments of naked hair shafts surrounded by granulomatous inflammation and dermal fibrosis. Collagen fibers are like those in hypertrophic scarring rather than those in real keloids. Also, histopathological examination can reveal different stages of inflammation in one lesion (13).

Diagnosis is usually clinical and biopsy is performed to exclude other conditions and dermatoses, such as tinea capitis, lichen planopilaris, hidradentitis supurativa, follicular cutaneous t-cell lymphoma, etc. (9). Dermoscopy can also be a useful aid to the clinical diagnosis, especially in detecting the early signs of perifollicular fibrosis $(14,15)$.

The first step in management is education and prevention, avoiding short haircuts and wearing helmets or hats, and avoiding picking, rubbing, scratching the affected area. Mild to moderate cases can be treated with potent or ultrapotent topical corticosteroids, alone or in combination with topical/oral antiobiotics or topical/oral retinoids (10). Re- cently it has been shown that targeted ultraviolet B phototherapy can be usefull to improve the clinical appearance of the lesions (16). Intralesional corticosteroids should be considered for a resistant cases and for the treatment of keloidal scarring (10). Laser therapy should be considered for the hair removal and/or softening of the keloidal plaques (17, 18). Several authors have reported that laser hair removal is an option to prevent relapsing folliculitis (13). If pustules and draining sinuses are present and bacterial culture is positive, oral antibiotics should be administered in addition to topical antibiotics (19). Surgical excision is the cornerstone of the management for extensive plaques and tumor-like masses $(9,11)$. An alternative surgical approach includes electrosurgery and cryosurgery. Electrosurgery allows for excision of the lesion with simultaneous coagulation of small vessels, however, cryosurgery provides varied responses to lesions, though it may be best suited for more vascular lesions $(20,21)$.

Radiotherapy should be reserved for the most severe and refractory cases, considering the side effects of such treatment (20).

\section{Abbreviations}

AKN - Acne keloidalis nuchae

FKN - Folliculitis keloidalis nuchae

\section{References}

1. Kaposi M. Über die sogennante Framboesia und mehrere andere Arten von papillaren neubildungel der Haut. Arch Dermatol Syphilol. 1869;1:382-423.

2. Cosman B, Wolff M. Acne keloidalis. Plast Reconstr Surg. 1972;50(1):25-30.

3. Azurdia RM, Graham RM, Wesmann K, Guerin DM, Parslew R. Acne keloidalis in Caucasian patients on cyclosporine following organ transplantation. $\mathrm{Br} \mathrm{J}$ Dermatol. 2000;143(2):465-7.

4. Leung AKC, Barankin B. Acne keloidalis nuchae. Clin Case Rep Rev. 2015;1(2):23-4.

5. Alexis A, Heath CR, Halder RM. Folliculitis keloidalis nuchae and pseudofolliculitis barbae: are prevention and effective treatment within reach? Dermatol Clin. 2014;32(2):183-91.

6. Kelly AP. Pseudofolliculitis barbae and acne keloidalis nuchae. Dermatol Clin. 2003;21(4):645-53.

7. George AO, Akanji AO, Nduka EU, Olasode JB, Odusan O. Clinical, biochemical and morphologic features of acne keloidalis in a black population. Int J Dermatol. 1993;32(10):714-6. 
8. Ogunbiyi A, Adedokun B. Perceived aetiological factors of folliculitis keloidalis nuchae (acne keloidalis) and treatment options among Nigerian men. Br J Dermatol. 2015;173 Suppl 2:22-5.

9. Mackay-Wiggan JM, Husain S. Acne keloidalis nuchae [Internet]. Waltham: UpToDate; 2015 [updated 2015 Sep 27; cited 2019 Sep 5]. Available from: https:// www.uptodate.com/contents/acne-keloidalis-nuchae.

10. Li K, Barankin B. Dermacase. Can you identify this condition? Acne keloidalis nuchae. Can Fam Physician. 2013;59(2):159-60.

11. Beckett N, Lawson C, Cohen G. Electrosurgical excision of acne keloidalis nuchae with secondary intention healing. J Clin Aesthet Dermatol. 2011;4(1):36-9.

12. Herzberg AJ, Dinehart SM, Kerns BJ, Pollack SV. Acne keloidalis. Transverse microscopy, immunohistochemistry, and electron microscopy. Am J Dermatopathol. 1990;12(2):109-21.

13. $\mathrm{Na} \mathrm{K}$, Oh SH, Kim SH. Acne keloidalis nuchae in Asians: a single institutional experience. PLoS One. 2017;12(12):e0189790.

14. Chouck C, Litaiem N, Jones M, Zeglaoui F. Acne keloidalis nuchae: clinical and dermoscopic features. BMJ Case Rep. 2017;2017:bcr-2017-222222.

15. Assouly P. Dermatoscopy of the hair and scalp. Ann Dermatol Venereol. 2012;139(10):652-67.
16. Okoye GA, Rainer BM, Leung SG, Suh HS, Kim JH, Nelson AM, et al. Improving acne keloidalis nuchae with targeted ultraviolet B treatment: a prospective, randomized, split-scalp comparison study. Br J Dermatol. 2014;171(5):1156-63.

17. Dragoni F, Bassi A, Cannarozzo G, Bonan P, Moretti S, Campolmi P. Successful treatment of acne keloidalis nuchae resistant to conventional therapy with 1064-nm ND:YAG laser. G Ital Dermatol Venereol. 2013;148(2): 231-2.

18. Esmat SM, Abdel Hay RM, Abu Zeid OM, Hosni HN. The efficacy of laser-assisted hair removal in the treatment of acne keloidalis nuchae: a pilot study. Eur $\mathrm{J}$ Dermatol. 2012;22(5):645-50.

19. Tamagawa K, Morioka D, Suminaga R, Zhang Z, Aoki A, Shibuya $Y$, et al. Surgical treatment of scarring alopecia associated with acne keloidalis nuchae. Modern Plastic Surgery. 2019;9(1):14-7.

20. Maranda EL, Simmons BJ, Nguyen AH, Lim VM. Treatment of acne keloidalis nuchae: a systematic review of the literature. Dermatol Ther (Heidelb). 2016;6(3): 363-78.

21. Layton AM, Yip J, Conliffe WJ. A comparison of the intralesional triamcinolone and cryosurgery in the treatment of acne keloids. Br J Dermatol. 1994;130(4): 498-501.

\section{Acne keloidalis nuchae: prikaz slučaja}

\section{Sažetak}

Acne keloidalis nuchae (AKN)/Folliculitis keloidalis nuchae(FKN) predstavlja hronično zapaljensko stanje koje zahvata folikule dlake dominantno lokalizovane u okcilipitalnoj regiji i zadnjoj strani vrata, dovodeći do nastanka hipertrofične ožiljne alopecije. Predstavljamo slučaj 59 godina stare osobe muškog pola, radnika u fabrici, bele rase, sa beličastim alopecičnim ovalnim plakom, dijametra oko $10 \mathrm{~cm}$, lokalizovanog u okcipi- talnoj regiji. Periferni deo plaka je bio blago inflamiran, sa grupicama „čuperaka“ terminalne dlake, dok je centralni deo odgovarao ožiljnoj alopeciji sa diskretnom neadherentnom skvamom. Promene su počele da se javljaju šest godina ranije, u vidu papula i pustula praćenih svrabom, koje su u nekim slučajevima zarastale ožiljavanjem. Relevantne sprovedene dijagnostičke i terapijske mere, biće opisane u prikazu ovog slučaja.

Ključne reči: Keloidne akne; Folikulitis; Dijagnoza; Alopecija; Ožiljak; Prikazi slučajeva; Terapija

Received 12.10.2019.

Accepted 27.10.2019. 